\title{
Sulfate Metabolism in Human Chondrocyte Cultures
}

\author{
Edith R. Schwartz, P. Roger Kirkpatrick, and Roby C. Thompson \\ From the Department of Orthopedics and Rehabilitation, University of Virginia \\ Medical Center, Charlottesville, Virginia 22901
}

A B S T R A C T The depletion of articular cartilage in the afflicted joints is a primary clinical feature of osteoarthritis. This disorder has been linked to a disturbance in the metabolism of the extracellular matrix components of this tissue. The mechanisms involved in the regulation of sulfated proteoglycan metabolism in articular cartilage were therefore studied by measuring the biosynthesis and distribution of ${ }^{35} \mathrm{~S}$-labeled glycosaminoglycans in chondrocyte cultures derived from normal and osteoarthritic tissue. Incorporation experiments were carried out at $\mathrm{pH} 7.0$ with $\left[{ }^{35} \mathrm{~S}^{2} \mathrm{Na}_{2} \mathrm{SO}_{4}\right.$ in the presence of fetal calf serum, human serum from normal or arthritic individuals, or a combination of these.

In the presence of heat-inactivated human sera, osteoarthritic chondrocytes incorporate about two times as much of the available sulfate into macromolecules as do normal chondrocytes. The deposition of newly synthesized sulfated macromolecules into the cell layer by these cells is lower, however, than that by normal cells.

In cultures of normal human chondrocytes, noninactivated sera from individuals with osteoarthritis stimulate sulfated proteoglycan biosynthesis more than equal concentrations of normal sera. The fraction of the newly synthesized material deposited into the cell layer was found to decrease with increasing serum concentrations. In the absence of serum, a 5- to 10 -fold increase in deposited sulfated macromolecules was found. The distribution within the cell layer between intra- and extracellular sites also was monitored by serum factors. Heat inactivation of the human serum component of the medium resulted in a $50 \%$ decrease in intracellular retention.

These data suggest that biosynthesis of sulfated proteoglycans and their retention in the matrix are modulated by cell and serum factors. Despite an increased uptake of radioactively labeled inorganic sulfate by osteoarthritic chondrocytes in cell culture, a lower rate of

A portion of this work was presented before the Orthopedic Research Society, Dallas, Texas, 15 January 1974.

Received for publication 25 January 1974 and in revised form 11 July 1974. deposition into the cell layer resulted in less matrix formation. This may be representative of the process leading to cartilage degradation in degenerative joint disease in vivo.

\section{INTRODUCTION}

Osteoarthritis is characterized in part by the destruction of articular cartilage in the afflicted joint. A suggested sequence of events includes the activation of the degradative enzymes in this tissue by some traumatic event, resulting in loss of joint surface tissue. Little is known about the histologic and biochemical events that initiate these processes. A concurrent stimulation of an intense repair mechanism that causes increased cell replication and synthesis of matrix material is not sufficient to offset the eventual tissue depletion (1).

To facilitate the study of this disorder, chondrocyte cultures derived from articular cartilage of normal and afflicted individuals were established for measurement of sulfated proteoglycan metabolism in the presence of normal or osteoarthritic human serum.

Since previous studies from these laboratories had shown that sulfated proteoglycan metabolism in chondrocyte cultures was strongly influenced by environmental $\mathrm{pH}$, and particularly that release of incorporated sulfate by the cell layer was inhibited in the alkaline $\mathrm{pH}$ range, these studies were all conducted at $\mathrm{pH}$ 7.0.1 We report here increased net biosynthesis accompanied by a reduced deposition into the cell layer of sulfated proteoglycans by chondrocytes derived from osteoarthritic human articular cartilage. Similar changes resulting from the inclusion of arthritic serum in the medium when normal chondrocytes were used will also be described.

\section{METHODS}

Human serum. Serum was obtained either from outpatients or from hospital patients shortly after admission and before administration of prophylactic antibiotics in preparation for surgery. Donors were selected from patients with idiopathic osteoarthritis. Individuals with known

${ }^{1}$ Submitted for publication. 
traumatic osteoarthritis were not included. Control sera were obtained from laboratory personnel or members of their families. All sera were from individuals above $30 \mathrm{yr}$ of age and were age-matched as closely as possible in each experiment.

In each set of experiments, identical concentrations of a given serum specimen were included in the media, in which both normal and osteoarthritic chondrocytes were grown and tested. No serum was used from any individual whose tissue was utilized for chondrocyte cultures.

Culture of chondrocytes. Chondrocytes were grown from normal or osteoarthritic cartilage obtained surgically from distal or proximal femoral surfaces from adult humans undergoing joint replacement or femoral head replacement after fracture. In the case of osteoarthritic specimens, care was taken to sample only those areas of the joint where remaining articular cartilage was present. Osteophytes and tissue near the bone cartilage margin were specifically excluded in all cases. Cultures were initiated as explants in $25-\mathrm{cm}^{2}$ or $75-\mathrm{cm}^{2}$ Falcon flasks (Falcon Plastics, Div. of BioQuest, Oxnard, Calif.) and after cell passage were maintained as monolayers at $37^{\circ} \mathrm{C}$ in the larger flasks for 3-8 mo before use. They were fed twice a week with Ham's F-12 medium supplemented with $10 \%$ fetal calf serum $(\mathrm{FCS})^{2}$, antibiotics, alpha-keto glutarate $(16.8 \mu \mathrm{g} /$ $\mathrm{ml})$, ascorbic acid $(50 \mu \mathrm{g} / \mathrm{ml})$, and magnesium sulfate $(200 \mu \mathrm{g} / \mathrm{ml})$. All the cell lines were maintained and passed under identical conditions. Cells were checked periodically for contamination by Mycoplasma in culture. None of the cells used ever gave a positive result.

Glycosaminoglycan metabolism. Kinetic experiments were conducted in duplicate or triplicate in Leighton tubes (11 $\times 38-\mathrm{mm}$ windows). Monolayer cultures were trypsinized and cells inoculated into $1 \mathrm{ml}$ of supplemented F-12 me-

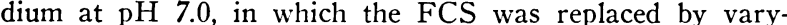
ing concentrations of experimental human serum, and 15 $\mu \mathrm{mM}$ HEPES buffer ( $N$-2-hydroxyethylpiperazine- $N^{1}-2$ ethane sulfonic acid) was included to maintain the environmental $\mathrm{pH}$ to $\pm 0.1 \mathrm{U}$. In a typical experiment, 24 Leighton tubes were set up from a large Falcon flask. The medium was replaced on days 3,7 , and 10 . The medium was removed $24 \mathrm{~h}$ later (day 11) and $1 \mathrm{ml}$ of sulfate-free, supplemented F-12 medium containing carrier-free $\mathrm{Na}_{2} \mathrm{SO}_{4}$ (ca. $40 \mu \mathrm{Ci} / \mathrm{ml}$ ) was added to each tube for $48 \mathrm{~h}$. When either protein-free or serum concentrations in the medium greater than $15 \%$ were required, inoculation of the entire series of tubes was performed in $\mathrm{pH}$-adjusted $\mathrm{F}-12$ medium containing $10 \%$ FCS. Media containing the varying human serum concentrations, or an absence of serum, were then introduced on day 3 and were used for feeding on days 7 and 10 , as above. Glycosaminoglycan metabolism was studied according to the method described by Fratantoni, Hall, and Neufeld (2) with some modifications.

The experiments described in Tables II and VI were conducted as described above except that the reaction vessels were $25-\mathrm{cm}^{2}$ Falcon flasks, and $4 \mathrm{ml}$ of medium was used. Triplicate determinations of normal and osteoarthritic cells were made in each experiment.

At the end of the 48-h incubation period, the medium was removed and dialyzed at $4^{\circ} \mathrm{C}$ for $6 \mathrm{~h}$ against $0.1 \mathrm{M}$ $\left(\mathrm{NH}_{4}\right)_{2} \mathrm{SO}_{4}$, followed by extensive dialysis against distilled water. The cell layer was washed with Gey's salt solution, detached from the flask by treatment with $0.25 \%$ trypsin in

${ }^{2}$ Abbrciations used in this paper: FCS, fetal calf serum; TCA, trichloroacetic acid.
Tyrode's solution at $37^{\circ} \mathrm{C}$ for $15 \mathrm{~min}$, and centrifuged. The cell pellet was washed with saline and extracted three times with $0.3-\mathrm{ml}$ aliquots of boiling $80 \%$ ethanol. The supernatant trypsin fraction, inactivated with an equal volume of Ham's F-12 medium containing $10 \%$ FCS, was dialyzed in a manner analogous to that used for the medium. The cells were dissolved in $1 \mathrm{~N} \mathrm{NaOH}$ with gentle heating for determination of radioactivity and of protein by the method of Lowry, Rosebrough, Farr, and Randall (3). In addition, aliquots of the dialyzed medium, dialyzed trypsin, and ethanol solution were counted in liquid scintillation solvent consisting of $1: 1$ ratio of toluene and methyl cellosolve containing, per liter $6 \mathrm{~g}$ PPO (2, 5-diphenyloxazole) and $0.6 \mathrm{~g}$ dimethyl POPOP (1, 4-bis-2-[4-methyl-5-phenyloxazolyl]benzene). Specific activity is defined as counts per minute per microgram cellular protein.

Qualitative analyses of the newly synthesized glycosaminoglycans were performed by chromatography on DEAE cellulose (4). The dialyzed medium and trypsin fractions were digested with papain $(0.25 \%)$ at $65^{\circ} \mathrm{C}$ for $18 \mathrm{~h}$ in $0.1 \mathrm{M}$ phosphate buffer, $\mathrm{pH} 6.5$, containing $0.01 \mathrm{M}$ cysteine and $0.01 \mathrm{M}$ EDTA. The proteins were precipitated with trichloroacetic acid (TCA) at a final concentration of $5 \%$, and the supernate was dialyzed to remove the TCA. Glycosaminoglycans were then precipitated with 3 vol of sodium acetate-saturated absolute ethanol at $0^{\circ} \mathrm{C}$. The precipitates were washed with absolute ethanol, ethanol: ether $(1: 1)$, and ether, freeze-dried, and resuspended in a small volume of water for subsequent ion-exchange chromatography. Protein-free preparations were also analyzed by electrophoresis on cellulose acetate strips by the method of Wessler, with barium acetate buffer (5). The strips were stained with $0.05 \%$ alcian blue in $95 \%$ ethanol saturated with sodium chloride. The isolated polysaccharides were further identified by their susceptibility toward treatment with chondroitinases $\mathrm{ABC}$ and $\mathrm{AC}$ and chondro-4- and chondro6-sulfatases (6).

Calculations. The total radioactivity incorporated per experiment was calculated by adding the ${ }^{35} \mathrm{~S}$ counts per minute in the dialyzed medium and trypsin fractions to those found in the ethanol extract and dissolved cell solutions. That part attributable to the cell layer equals the total radioactivity minus the amount contributed by the dialyzed medium fraction. All results are the averages of duplicate or triplicate experiments.

\section{RESULTS}

On chromatography, more than $80 \%$ of the sulfate-labeled glycosaminoglycans from the medium and cell layer fractions were eluted in the chondroitin sulfate fraction. No significant quantitative difference was discerned between material synthesized in the presence of normal or osteoarthrit:c serum. On electrophoresis, the material migrated as chondroitin sulfate. Quantitation of chondroitin 4- and chondroitin 6-sulfate by the method of Saito, Yamagata, and Suzuki (6) indicated over 50\% of the chondroitin sulfate was present as chondroitin6-sulfate in a normal cell line.

The rather slow growth exhibited by chondrocytes derived from adult articular cartilage necessitated the use of experimental vessels with small surface areas. Since cell growth occurs equally well in plastic tubes or glass 
TABLE I

Biosynthesis of Sulfated Proteoglycans in Normal and Osteoarthritic Human Chondrocyte Cultures

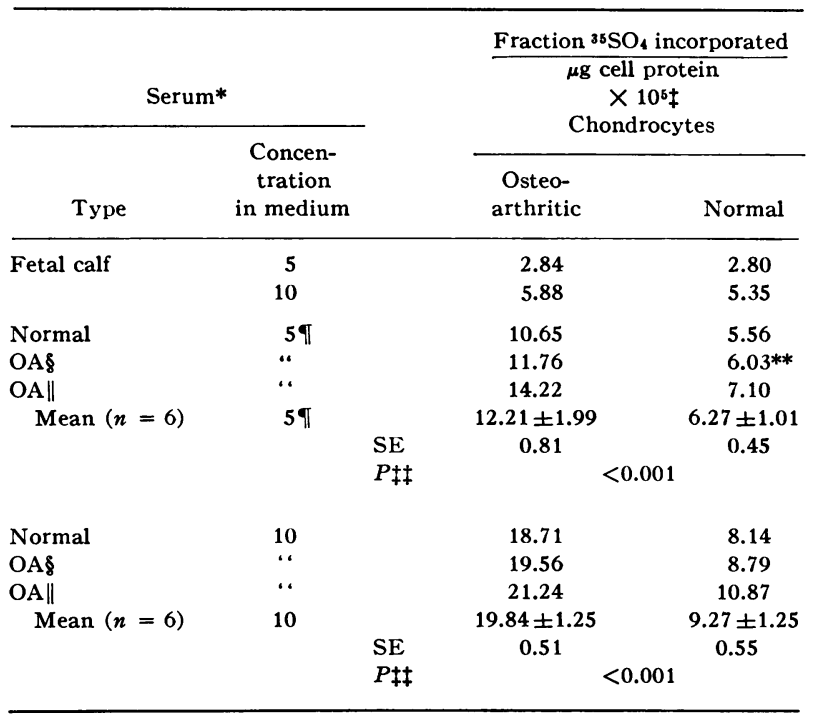

OA, osteoarthritis.

* Heat-inactivated for $30 \mathrm{~min}$ at $56^{\circ} \mathrm{C}$.

$\ddagger$ Average of duplicate determinations.

\& Patient P. G.

$\|$ Patient O. P.

Tा Supplemented with $5 \%$ FCS.

** Single determination only.

\# Standard Student $t$ test.

Leighton tubes after trypsinization from Falcon flasks, the latter were chosen for most of these studies.

\section{Biosynthesis of sulfated proteoglycans}

Cellular effects. In the presence of $10 \%$ heat-inactivated human serum in the medium, chondrocytes from patients with osteoarthritis incorporate about two times as much of the available inorganic sulfate into macromolecules per unit of cell protein as do chondrocytes derive from normal adults (Table I). This difference, not nearly as great when the medium was supplemented solely with FCS, was, however, observed when equal parts of human serum FCS were present. The sulfate incorporation by osteoarthritic chondrocytes was significantly higher $(P<0.001)$ in the presence of either $5 \%$ or $10 \%$ human serum.

Increased sulfate incorporation with increasing concentrations of human and fetal calf sera in the media was exhibited by both normal and osteoarthritic chondrocytes. Thus, when the FCS concentration in the medium was doubled from 5 to $10 \%$, biosynthesis of sulfated proteoglycans, as reflected in sulfate incorporation, also doubled. When normal or osteoarthritic serum concentrations were doubled, the biosynthesis rates increased 75 and $50 \%$, respectively.

\footnotetext{
${ }^{3}$ Unpublished observation.
}

TABLE II

Sulfate Incorporation in Normal and Osteoarthritic Human Chondrocyte Cultures

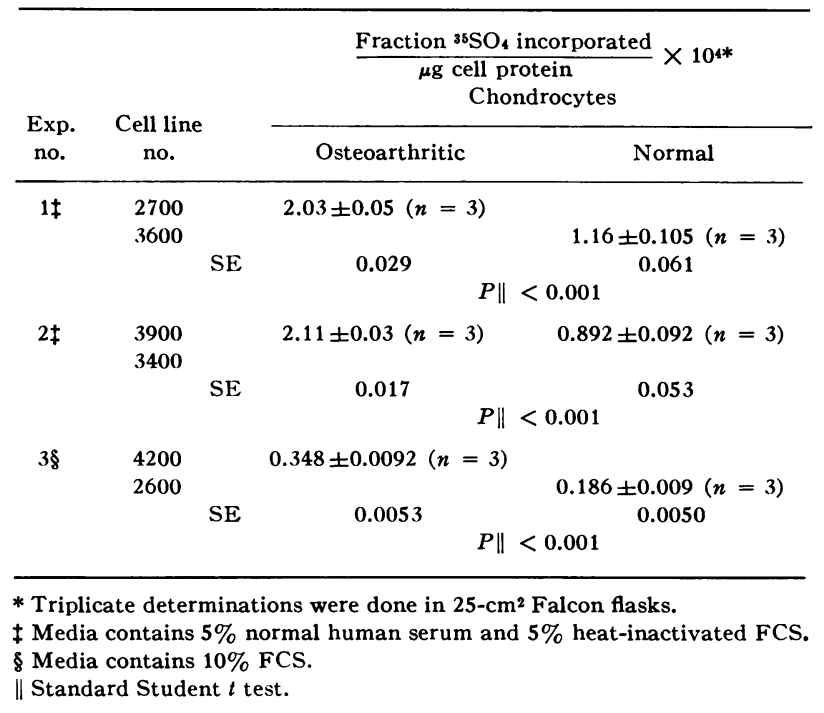

Further verification of increased biosynthesis of sulfated proteoglycans in osteoarthritic chondrocytes is shown in the data presented in Table II. Sulfate incorporation was measured in cell cultures derived from tissue of three normal and three osteoarthritic patients. In each experiment, sulfate incorporation was significantly higher in the osteoarthritic cell line.

Serum effects. Differences in the biosynthesis of sulfated proteoglycans per unit of cell protein by normal chondrocytes were found when the medium was supplemented with normal or osteoarthritic serum. The effects of 5 or $10 \%$ normal or osteoarthritic serum are shown in Table III. The former was supplemented with $5 \%$ inactivated FCS to bring the final serum concentration to $10 \%$ also. On the average, 5 and $10 \%$ osteoarthritic serum increased the biosynthesis 50 and $100 \%$ over the normal control value, respectively. These increases were statistically significant with both $5 \%(P<$ $0.01)$ and $10 \%(P<0.002)$ human serum present in the medium. A comparable rise was not observed when heat-inactivated human serum was used. It is therefore unlikely that the observed difference was due solely to variations in the existing somatomedin levels, since this polypeptide has been reported to withstand boiling temperature (7).

\section{Cellular patterns}

The integrity of chondrocyte culture systems, particularly with respect to phenotypic expression on cell passage, has been investigated in many laboratories (8-10). Sulfated proteoglycan biosynthesis by third and fifth passage chondrocytes derived from the same cell 
TABLE III

Effect of Human Serum on the Biosynthesis of Sulfated Proteoglycans in Chondrocyte Cultures*

\begin{tabular}{|c|c|c|c|c|}
\hline \multicolumn{3}{|c|}{ Serum concentration in medium } & \multirow{2}{*}{\multicolumn{2}{|c|}{$\begin{array}{c}\text { Fraction }{ }^{35} \mathrm{SO}_{4} \text { incorporated } \\
\mu \mathrm{g} \text { cell protein } \\
\times 10^{5} \ddagger 8\end{array}$}} \\
\hline \multirow{3}{*}{$\begin{array}{l}\text { Inactivated } \\
\text { fetal calf }\end{array}$} & \multirow{2}{*}{\multicolumn{2}{|c|}{$\begin{array}{l}\text { Not inactivated } \\
\text { human }\end{array}$}} & & \\
\hline & & & Normal & $\mathrm{OA}$ \\
\hline & Normal & $\mathrm{OA}$ & serum & serum \\
\hline \multicolumn{5}{|c|}{$\%$} \\
\hline 5 & $5 \|$ & & 3.17 & \\
\hline 5 & & 5 & & 5.82 \\
\hline 5 & 59 & & 5.00 & \\
\hline 5 & & $5 \pi$ & & 7.48 \\
\hline \multirow{2}{*}{\multicolumn{3}{|c|}{$\begin{array}{l}\text { Mean }(n=4) \\
\text { SE }\end{array}$}} & $4.09 \pm 1.24$ & $6.65 \pm 1.15$ \\
\hline & & & 0.62 & 0.58 \\
\hline \multirow[t]{5}{*}{$P * *$} & & & \multicolumn{2}{|c|}{$<0.01$} \\
\hline & $10 \|$ & & 4.40 & \\
\hline & & $10 \|$ & & 11.45 \\
\hline & $10 \uparrow$ & & 6.55 & \\
\hline & & $10 \Phi$ & & 11.63 \\
\hline \multirow{3}{*}{\multicolumn{3}{|c|}{$\begin{array}{l}\text { Mean }(n=4) \\
\text { SE } \\
P^{* *}\end{array}$}} & $5.48 \pm 1.52$ & $11.54 \pm 1.66$ \\
\hline & & & 0.76 & 0.83 \\
\hline & & & \multicolumn{2}{|c|}{$<0.002$} \\
\hline
\end{tabular}

OA, osteoarthritis.

* Chondrocytes derived from normal articular cartilage.

Incorporation period of $48 \mathrm{~h}$

$\S$ Average values for duplicate determinations.

II Female patient and control.

II Male patient and control.

** Standard Student $t$ test.

line is shown in Table IV. In the presence of identical concentrations of arthritic or arthritic and normal serum, the fraction of available ${ }^{35} \mathrm{SO}_{4}$ incorporated from the labeling medium per unit of cell protein was similar for the two cell culture systems. The mechanisms operative in the biosynthesis of sulfated macromolecules appear to be conserved in the processes of cell passage used in our laboratories.

TABLE IV

Similarity in $\left[{ }^{36} \mathrm{~S}\right]$ Proteoglycan Biosynthesis of Normal Chondrocytes in Different Cell Passages

\begin{tabular}{|c|c|c|c|}
\hline \multicolumn{2}{|c|}{ Serum } & \multicolumn{2}{|c|}{$\begin{array}{c}\frac{\text { Fraction }{ }^{35} \mathrm{SO}_{4} \text { incorporated }}{\mu \mathrm{g} \text { cell protein }} \\
\times 10^{5 *}\end{array}$} \\
\hline \multirow[b]{2}{*}{ Type } & \multirow{2}{*}{$\begin{array}{l}\text { Concentration } \\
\text { in medium }\end{array}$} & \multicolumn{2}{|c|}{ Passage } \\
\hline & & Third & Fifth \\
\hline & $\%$ & & \\
\hline OA $\ddagger$ & 6 & 13.6 & 11.1 \\
\hline OAt & 12 & 18.1 & 14.1 \\
\hline OAf & 18 & 24.4 & 22.0 \\
\hline OA & 12 & 2.3 .5 & 21.2 \\
\hline+ & + & & \\
\hline normal§ & 6 & & \\
\hline
\end{tabular}

OA, osteoarthritis.

* Average value of duplicate determinations.

$\ddagger$ Male patient $\mathrm{C}$. $\mathrm{M}$.

\& Male control.
TABLE V

Effect of Cell Origin on Distribution of Newly Synthesized Sulfated Proteoglycans between Medium and Cell Layer in Chondrocyte Cultures

\begin{tabular}{|c|c|c|c|}
\hline & & \multirow{2}{*}{\multicolumn{2}{|c|}{$\frac{\frac{\left[{ }^{35} \mathrm{~S}\right] \mathrm{PG} \text { in cell layer } \ddagger}{\text { Total }\left[{ }^{35 \mathrm{~S}}\right] \mathrm{PG}}}{\text { Chondrocyte type }}$}} \\
\hline \multicolumn{2}{|c|}{ Serum* } & & \\
\hline Type & $\begin{array}{l}\text { Concentration } \\
\text { in medium }\end{array}$ & Normal & Osteoarthritic \\
\hline & $\%$ & & $\%$ \\
\hline Normal & $5 \S$ & 17.23 & 10.88 \\
\hline Normal & 10 & 17.79 & 10.78 \\
\hline $\mathrm{OA} \|$ & $5 \S$ & 12.24 & 10.22 \\
\hline OA & 58 & 13.70 & 8.95 \\
\hline OA $\|$ & 10 & 18.33 & 9.73 \\
\hline OA & 10 & 17.28 & 9.42 \\
\hline
\end{tabular}

Statistical analysis of data: to determine whether the distribution was significantly different in the normal and osteoarthritic cell line, a two-way analysis of variance was applied to the data. In the presence of normal serum, the fraction deposited in the cell layer was significantly higher in normal cells $(P<0.001)$. Similarly, the fraction deposited in the cell layer of normal cells was also significantly higher $(P<0.001)$ in the presence of osteoarthritic serum. Although variation in the concentration of normal serum in the medium had no effect, a larger proportion of the sulfated proteoglycans was deposited in the presence of the higher level of osteoarthritic serum $(P<0.005)$. OA, osteoarthritis; PG, proteoglycan. * Heat-inactivated at $56^{\circ} \mathrm{C}$ for $30 \mathrm{~min}$.

$\ddagger$ Average value for duplicate determinations.

\$ Supplemented with $5 \%$ inactivated FCS.

II Patient P. G.

- Patient O. P.

The uptake of ${ }^{35} \mathrm{SO}_{*}$ increases with increasing concentrations of osteoarthritic human serum (Table IV). A similar increase in the incorporation of ${ }^{35} \mathrm{SO}_{4}$ with increasing levels of normal human serum was also observed (data not given). This effect may result from higher levels of somatomedin, introduced into the test media by the greater concentrations of human sera present.

TABLE VI

Deposition of Newly Synthesized Sulfated Proteoglycans into the Cell Layer in Normal and Osteoarthritic

Chondrocytes

\begin{tabular}{cccc}
\hline $\begin{array}{c}\text { Expt. } \\
\text { no. }\end{array}$ & $\begin{array}{c}\text { Cell } \\
\text { line }\end{array}$ & $\begin{array}{c}\text { Cell } \\
\text { type }\end{array}$ & $\begin{array}{c}\text { Fraction }\left[{ }^{35} \mathrm{~S}\right] \text { proteoglycans in cell layer } \\
\mu \text { g cell protein } \\
\text { Ratio (normal:OA)* }\end{array}$ \\
\hline $1 \ddagger$ & 3600 & $\mathrm{~N}$ & 1.26 \\
& 2700 & OA & \\
$2 \ddagger$ & 3400 & $\mathrm{~N}$ & 1.32 \\
& 3900 & OA & 1.36 \\
$3 \S$ & 2600 & $\mathrm{~N}$ & \\
& 4200 & OA & \\
\end{tabular}

OA, osteoarthritis.

* Average value of triplicate determinations in $25-\mathrm{cm}^{2}$ Falcon flask for each cell line.

$\ddagger$ Medium contains 5\% normal human serum and 5\% heat-inactivated FCS.

$\S$ Medium contains $10 \% \mathrm{FCS}$.

Sulfate Metabolism in Chondrocytes 
TABLE VII

Effect of Serum Concentration on Distribution of Newly Synthesized Sulfated

Proteoglycans between Medium and Cell Layer in

Chondrocyte Cultures

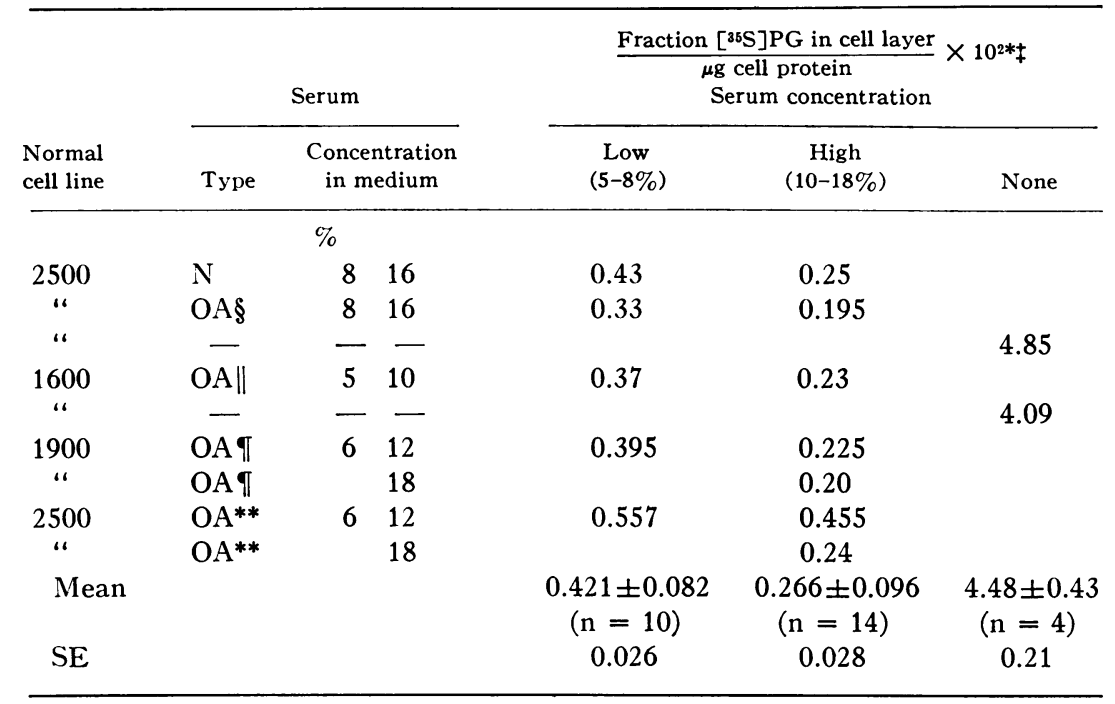

Statistical analysis of data: to determine whether deposition into the cell layer was a function of the presence or absence of serum; the serum concentration; the serum type; and/or the cell line origin, the data were subjected to the standard Student $t$ test and to two-way analysis of variance. Standard $t$ test on serum concentration: The deposition into the cell layer was significantly higher in the absence of serum (low vs. none, $P<0.0001$; high vs. none, $P<0.0001$ ). Furthermore, it was significantly higher in the presence of low than with high concentrations of serum $(P<0.001)$. A two-way analysis of variance of serum type vs. concentration showed the significant decrease in the deposition of $\left[{ }^{35} \mathrm{~S}\right] \mathrm{PG}$ in the cell layer with increasing serum concentration $(P<0.002)$ but revealed no significant difference on this effect by normal or osteoarthritic sera $(P \approx 0.06)$. A similar two-way analysis of variance of cell line origin vs. osteoarthritic serum concentrations supported the significance of the effect of serum concentration levels on $\left[{ }^{35} \mathrm{~S}\right] \mathrm{PG}$ deposition $(P<0.005)$ but indicated no dependence on cell-line history $(P \approx \mathrm{NS})$. OA, osteoarthritis, PG, proteoglycans.

* Fraction in cell layer calculated as described in Methods.

$\ddagger$ Average of duplicate determinations.

$\S$ Male patient H. B.

\| Female patient V.S.

II Male patient C. M.

** Female patient M. S.

\section{Product distribution}

Cellular effects. The distribution of newly synthesized sulfated macromolecules between medium and cell layer fractions is determined, in part, by the ratio of cell layer surface and medium volume, as well as the time interval between the administration of the labeling medium and the previous medium change. When normal chondrocytes were used, approximately $85 \%$ of the newly synthesized sulfated proteoglycans were found in the medium fraction when the experimental procedures described in the Methods section were followed. The remainder, about $15 \%$, was found in the cell layer (Table V). With osteoarthritic cells, the fraction deposited in the cell layer was reduced to about $10 \%$. The distribution between the medium and cell layer fractions therefore appeared to be dependent on the origins of the cells in culture. When compared with osteoarthritic cells, the fraction deposited in the cell layer of normal cell cultures was significantly higher in the presence of both normal $(P<0.001)$ or osteoarthritic $(P<0.001)$ sera. The reduction in matrix formation was not due to a smaller cell density, since a comparable difference appears when expressed per unit of cell protein. This is 
shown in Table VI, where deposition of sulfated proteoglycans into the cell layer is given on a protein basis. These data are derived from three sets of experiments pairing a different normal and a different osteoarthritic cell line in each set. Deposition of sulfated macromolecules into the cell layer was always higher in the normal cell line.

Serum effects. In addition to cellular effects, the deposition of newly synthesized sulfated macromolecules into the cell layer was also modulated by the concentration of serum present in the medium. In the $a b-$ sence of serum, the fraction deposited per microgram of cell protein was several-fold higher than when proteinsupplemented medium was used (Table VII).

At low concentrations of noninactivated serum (5$8 \%$ ), the fraction deposited into the cell layer was significantly greater than with higher concentrations (10$18 \%)$ of serum $(P<0.001)$. The relative decrease in the deposition of newly synthesized materials into the cell layer was observed with a variety of test systems, which included the use of three different cell lines and one normal and four osteoarthritic serum specimens. Statistical analysis showed that the concentration-dependent deposition into the cell layer was independent of the serum origin $(P>0.05)$ or the cellline history $(P \approx \mathrm{NS})$.

\section{Intracellular accumulation}

The distribution of newly synthesized sulfated macromolecules within the cell layer also appeared to be dependent on serum components in the culture medium. The fraction of total labeled proteoglycans in the cell layer retained intracellularly was approximately two times greater in the presence of noninactivated compared with heat-inactivated human serum (Table VIII). The higher intracellular accumulation was evident in the presence of both noninactivated normal $(P=2.5 \times$ $\left.10^{-4}\right)$ and noninactivated osteoarthritic sera $(P=3.6 \times$ $10^{-3}$ ). This suggests regulation of product release by circulating factors at the cellular level.

\section{DISCUSSION}

The biochemical events preceding and accompanying the disintegration of articular cartilage in osteoarthritis have been widely investigated in various experimental animal models of degenerative joint disease and numerous human cases. Differences in proteoglycan composition (11), collagen structure (12), and lysosomal enzyme activities (13-15) in pathologic tissue specimens have been described. Increased cellular and biosynthetic activity has been found in animal studies in vivo and in vitro. Increased sulfate uptake per gram of dried osteoarthritic cartilage when compared to controls was shown by Meachim, Ghadially, and Collins (16). Bollet,
TABLE VIII

Effect of Human Serum on the Distribution of Sulfated Proteoglycans in the Cell Layer of Chondrocyte Cultures

\begin{tabular}{|c|c|c|c|c|}
\hline \multirow[b]{4}{*}{$\begin{array}{l}\text { Expt. } \\
\text { no. }\end{array}$} & \multicolumn{4}{|c|}{$\left[{ }^{35} \mathrm{~S}\right] \mathrm{PG}$ in Cells/ $\left.{ }^{36} \mathrm{~S}\right] \mathrm{PG}$ in Cell Layer* } \\
\hline & \multicolumn{4}{|c|}{ Serum in medium $\ddagger$} \\
\hline & \multicolumn{2}{|c|}{ Normal } & \multicolumn{2}{|c|}{ Osteoarthritic } \\
\hline & $\begin{array}{c}\text { Not } \\
\text { inactivated }\end{array}$ & $\begin{array}{c}\text { Heat- } \\
\text { inactivated }\end{array}$ & $\begin{array}{c}\text { Not } \\
\text { inactivated }\end{array}$ & $\begin{array}{c}\text { Heat- } \\
\text { inactivated }\end{array}$ \\
\hline $1 \S:$ & 25.7 & 13.0 & 27.2 & 12.8 \\
\hline $2 \S \circlearrowleft$ & 22.4 & 13.8 & 23.5 & 11.4 \\
\hline 3 & 25.7 & 12.0 & 22.0 & 18.9 \\
\hline \multirow[t]{2}{*}{$4 \boldsymbol{\top}$} & 22.3 & 10.6 & 25.3 & 8.7 \\
\hline & \multicolumn{2}{|c|}{$P 2.5 \times 10^{-4 * *}$} & \multicolumn{2}{|c|}{$3.68 \times 10^{-3 * *}$} \\
\hline
\end{tabular}

PG, proteoglycans.

* Average values for duplicate determinations after 48-h incorporation period.

$\ddagger 10 \%$ total.

$\S$ Equal mixtures of $\mathrm{FCS}$ and human serum.

fi Female patient L. A. and female control.

- Female patient H. F. and male control.

** $P$ values derived from one-way analysis of variance.

Hardy, and Sturgill had found increased specific activity of sulfated polysaccharides in osteoarthritic cartilage (17). The question remained, however, whether there was more synthesis per chondrocyte, more chondrocytes per unit of tissue, or differences in the products synthesized. Despite evidence of increased sulfate incorporation, histological studies correlated advances in the diseased state with increasing loss of metachromatic staining from the cartilage surface to the interior regions of the tissue. Furthermore, an elevation of joint fluid sulfate (18) and elevation of aryl sulfatase A and $B$ activities (15) have been measured in degenerative arthritis. Our objective, therefore, was to compare sulfate metabolism of normal and osteoarthritic chondrocytes in culture systems under controlled environmental conditions to understand the regulatory mechanisms that apparently malfunction in the pathologic state. The data presented here support previous findings of elevated sulfate incorporation in osteoarthritis. Most importantly, however, they provide evidence that the information for the increased biosynthesis may be inherent in the chondrocytes derived from the pathologic tissue and appears to be conserved on cell passage. Since the products synthesized by normal and osteoarthritic cells migrated similarly on electrophoresis, it is unlikely that the significant difference in increased incorporation was principally due to variation in the degree of sulfation of the proteoglycans, but rather does indeed reflect increased biosynthesis.

The paradox of cartilage depletion despite increased biosynthesis of sulfated macromolecules appears to be duplicated in the cell culture system of chondrocytes 
derived from osteoarthritic tissue. These cells, when contrasted to those derived from normal articular cartilage, deposit a smaller fraction of the newly synthesized macromolecular products into the cell layer in a variety of cell culture conditions. The decrease in the deposition could result from variation in chain size synthesis or conformation that prevents proper aggregation for stable matrix formation. Alternatively, if the relative catabolic rate was elevated in osteoarthritic cells, the newly synthesized molecules might be partially degraded before they could be incorporated into the matrix of the cell layer. By analogy, these factors inherent in the osteoarthritic chondrocytes might prevent normal rates of matrix formation in vivo. Further studies are needed to decide whether cartilage depletion in degenerative joint disease results from an abnormality in the products synthesized or assembled, from degradative or other cellular factors, or from a combination of these.

A unifying hypothesis for the biochemical basis of osteoarthritis will need to include the role played by circulating serum factors. Increased biosynthesis of sulfated proteoglycans, as reflected in elevated sulfate uptake, also was observed in the presence of sera from osteoarthritic patients when compared to sera from agematched controls. The increase as measured in normal chondrocyte culture systems was found to be concentration dependent.

The higher rate of sulfated proteoglycan biosynthesis seen in the presence of osteoarthritic sera could result from interactions with one or more serum components. Since the increase was not found with heat-inactivated serum, it is unlikely that a difference in the somatomedin level per se was the determining factor. It is possible, however, that variation in the concentrations of other polypeptides may be responsible for the measured difference. It has recently been shown, for example, that insulin and somatomedin bind competitively to chondrocytes (19). Whether the newly described family of "growth-promoting" substances are synthesized by chondrocytes themselves is unclear at this time.

The question of whether osteoarthritic serum causes an excessive reduction in the deposition of newly synthesized sulfated macromolecules into the cell layer is more difficult to resolve, since as presented under $\mathrm{Re}^{-}$sults, a net decrease of sulfated proteoglycans per unit of cell protein was deposited in the cell layer with increasing serum concentrations. Similar findings (data not given) were made with normal serum in the medium. The data presented do suggest, however, that the extent of biosynthesis and deposition of newly sulfated proteoglycans are modulated by both cellular and circulating factors. The latter may include biosynthetic regulators, binding factors, or enzymes that catalyze the degradation of the macromolecules before assembly and deposition have occurred in the extracellular matrix. The action of these circulating factors on the articular cartilage may be mediated through the synovial fluid.

The release of newly synthesized sulfated proteoglycans from intracellular sites in chondrocytes also appears to be regulated by circulating factors. The intracellular accumulation in the presence of noninactivated human serum was nearly double that found in the presence of comparable heat-inactivated serum. Experiments have been initiated to isolate this heat-labile component and to establish whether the site of action of this factor is directly on the cellular membrane, or perhaps on other membranes used to assemble export vesicles.

A previously proposed pathway for lysosomal enzyme action in degenerative joint diseases assigns initial cartilage matrix destruction to be the trigger for synovitis. Further cartilage destruction then occurs through the action of enzymes in the synovial fluid, which are carried to the articular cartilage.

The data presented here might extend this hypothesis to assign a more extensive transport role to the synovial fluid. In addition to synovial enzymes, effector molecules derived from the serum may be carried via the synovial fluid to cellular sites in articular cartilage. This may be accentuated in the fibrillated surface areas present in the degenerative tissue. Furthermore, the alteration in the biochemical metabolism inherent in the osteoarthritic chondrocyte strongly supports the role of cartilage as a site of active cellular response to pathogenesis in degenerative joint disease.

\section{ACKNOWLEDGMENTS}

The authors are grateful to Dr. Owen Hendley for many helpful discussions and to Dr. William O'Brien for assistance in the statistical analysis of data.

This work was supported in part by Grant AM 16606 from the National Institutes of Health and a grant from the John Hartford Foundation.

\section{REFERENCES}

1. Mankin, H. J. 1973. Biochemical and metabolic abnormalities in osteoarthritic human cartilage. Fed. Proc. 32 : $1478-1480$.

2. Fratantoni, J. C., C. W. Hall, and E. F. Neufeld. 1968. The defect in Hurler's and Hunter's syndromes. - Faulty degradation of mucopolysaccharide. Proc. Natl. Acad. Sci. U. S. A. 60: 699-706.

3. Lowry, O. H., N. J. Rosebrough, A. L. Farr, and R. J. Randall. 1951. Protein measurement with the Folin phenol reagent. J. Biol. Chem. 193: 265-275.

4. Silbert, J. E., and S. DeLuca. 1969. Biosynthesis of chondroitin sulfate. J. Biol. Chem. 244: 876-881.

5. Wessler, E. 1968. Analytical and preparative separation of acidic glycosaminoglycans by electrophoresis in barium acetate. Anal. Biochem. 26: 439-444.

6. Saito, H., T. Yamagata, and S. Suzuki. 1968. Enzymatic methods for the determination of small quantities of isomeric chondroitin sulfate. J. Biol. Chem. 243: 15361542 
7. Van Wyck, J. J., L. E. Underwood, R. C. Lister, and R. N. Marshall. '1973. The somatomedins. A new class of growth-regulating hormones? Am. J. Dis. Child. 126: 705-711.

8. Layman, D. L., L. Sokoloff, and E. J. Miller. 1972. Collagen synthesis by articular chondrocytes in monolayer culture. Exp. Cell Res. 73: 107-112.

9. Lavietes, B. B. 1971. Kinetics of matrix synthesis in cartilage cell cultures. Exp. Cell Res. 68: 43-48.

10. Chacko, S., J. Abbott, S. Holtzer, and H. Holtzer. 1969. The loss of phenotypic traits by differentiated cells. VI. Behavior of the progeny of a single chondrocyte. J. Exp. Mcd. $130:$ 417-442.

11. Mankin, H. J., and L. Lippiello. 1971. The glycosaminoglycans of normal and arthritic cartilage. J. Clin. Invest. 50: $1712-1719$.

12. Nimni, M., and K. Deshmukh. 1973. Differences in collagen metabolism between normal and osteoarthritic human articular cartilage. Scicnce (Wash. D. C.). 181: 751-752.

13. Thompson, R. C., and I. Clark. 1970. Acid hydrolases in slices of articular cartilage and synovium from normal and abnormal joints. Proc. Soc. Exp. Biol. Med. 133: 1102-1108.

14. Ehrlich, M. G., H. J. Mankin, and B. V. Treadwell. 1973. Acid hydrolase activity in osteoarthritic and normal human cartilage. J. Bone Jt. Surg. 55A : 1068-1076.

15. Schwartz, E. R., R. Ogle, and R. C. Thompson. 1974. Aryl sulfatase activities in normal and pathologic human articular cartilage. Arthritis Rheum. 17: 455-467.

16. Meachim, G., F. N. Ghadially, and D. H. Collins. 1965. Regressive changes in the superficial layer of articular cartilage. Ann. Rheum. Dis. 24: 23-30.

17. Bollet, A. J., J. R. Hardy, and B. C. Sturgill. 1963. Chondroitin sulfate concentration and protein-polysaccharide composition of articular cartilage in osteoarthritis. J. Clin. Invest. 42: 853-859.

18. Chrisman, O. D., C. O. Bechtol, R. R. Coelho, and R. Brennan. 1958. Sulfur metabolism in cartilage. Joint fluid'sulfate. J. Bone Jt. Surg. Am. Vol. 40: 457-461.

19. Hintz, R. L., D. R. Clemmons, L. E. Underwood, and J. J. Van Wyk. 1972. Competitive binding of somatomedin to the insulin receptors of adipocytes, chondrocytes, and liver membranes. Proc. Natl. Acad. Sci. U. S. A. 69: 2351-2353. 